Journal of Applied Pharmaceutical Science Vol. 6 (02), pp. 130-134, February, 2016

Available online at http://www.japsonline.com

DOI: 10.7324/JAPS.2016.60220

ISSN 2231-3354 (cc) EY-NC-SA

\title{
Antioxidant activity and determination of bioactive compounds by GC-MS in fruit methanol extracts -a comparative analysis of three Atalantia species from south India
}

\author{
Arun K Das, Sudhakar Swamy* \\ Department of Plant Sciences School of Biological Sciences Madurai Kamaraj University Madurai- 625 021, India.
}

\begin{tabular}{|c|c|}
\hline ARTICLE INFO & ABSTRACT \\
\hline Article history: & \multirow{9}{*}{$\begin{array}{l}\text { The members of genus Atalantia are widely used in Traditional, Folk and Ayurvedic systems of Medicine; of } \\
\text { which three species are found in south India namely A. monophylla, A. racemosa, A. wightii. The fruits of these } \\
\text { plants are picked and widely consumed by the tribal people. The present study aims to test the anti-oxidant } \\
\text { potential of the methanol extracts of fruits and also to identify the bioactive compounds present in the extracts } \\
\text { through GC/MS analysis. Among the three fruits tested for the antioxidant activity using the DPPH method, the } \\
\text { crude methanolic extracts of } A \text {. monophylla shows higher potential. The } \mathrm{IC}_{50} \text { value calculated was found to be } \\
336.84 \mu \mathrm{g} / \mathrm{ml} \text { for } A \text {. monophylla, } 348.75 \mu \mathrm{g} / \mathrm{ml} \text { for } A \text {. racemosa and } 375.64 \mu \mathrm{g} / \mathrm{ml} \text { for } A \text {. wightii. Ascorbic acid } \\
\text { used as standard had an IC } 50 \text { value of } 103.03 \mu \mathrm{g} / \mathrm{ml} \text {. Total antioxidant capacity was expressed as ascorbic acid } \\
\text { equivalent and was calculated using the Phosphomolybdenum method. The methanol extract of } A \text {. monophylla, } \\
\text { A. racemosa and A. wightii determined by phosphomolybdenum method exhibited significant antioxidant activity } \\
\text { of } 686 \mathrm{mg} / \mathrm{g}, 592 \mathrm{mg} / \mathrm{g} \text { and } 655 \mathrm{mg} / \mathrm{g} \text { ascorbic acid equivalent respectively. Also the bioactive compounds in the } \\
\text { Methanol extracts were evaluated using GC/MS. }\end{array}$} \\
\hline Received on: & \\
\hline 08/09/2015 & \\
\hline Accepted on: 12/ & \\
\hline Available online: $27 / 02 / 2016$ & \\
\hline Key words: & \\
\hline Atalantia, GC/MS, & \\
\hline Antioxidant activity, & \\
\hline Bioactive compounds. & \\
\hline
\end{tabular}

\section{INTRODUCTION}

The genus Atalantia Correa (Family: Rutaceae) comprises of about 11 very closely related species (Swingle and Reece, 1967); of which three species are found in south India. Atalantia monophylla (Roxb.) DC. commonly called as wild lime is commonly seen in the dry evergreen forests of south India from the coastal regions to about $600 \mathrm{~m}$ altitude. Atalantia racemosa Wight. (Bombay Atalantia) is seen in the evergreen forests of Peninsular India and Srilanka from about $150 \mathrm{~m}$ to about $1000 \mathrm{~m}$. It is considered as a replacement taxon for $A$. monophylla. Atalantia wightii is endemic to shola forests of Western Ghats and is commonly referred to as Nilgiri Atalantia. It is distributed from $100 \mathrm{~m}$ to about $1700 \mathrm{~m}$.

The members of the genus Atalantia are important plants in the understory layer of the forests. They are commonly found in the disturbed areas such as roadside, forest edges etc. and also along the sides of the streams and periphery of other water bodies where sufficient sunlight is available.

* Corresponding Author

Email: swamypsplantscience@gmail.com
It is a source of food for larvae of several pollinators and also a source of food for seed dispersal agents (Vanitharani et al., 2011; Rajasekhar et al., 2006; Storz and Kunz, 1999; Punekar, 2002). Also the leaves of A. monophylla are an important source of food for the Asiatic elephant (Elephas maximus) (Mohapatra et al., 2013). Fruit, leaves and roots of the members of genus Atalantia are used for medicinal purposes. Traditional medicinal practitioners use the leaves of A. monophylla for the treatment of rheumatoid pain and glandular swelling. A decoction of the leaves is often applied for itching and other skin complaints (Panda, 2004) and also in treatment of dysentery (Jain, 1991). The leaves and roots are used as blood purifier and roots are given in cough and dysentery. Berries yield warm oil, which is valuable application in chronic rheumatism, paralytic limb and as stimulant (Krithikar and Basu, 1993; Panda, 2004). Fruit juice is anti-bilous and the fruit juice is consumed to treat stomach disorder by Kani tribals (Khare, 2007; John de britto and Mahesh, 2007). The juice pressed out from fruits heals endemic Cachexia (pitao) (Jain, 1991). Root is antispasmodic (Panda, 2004), antiseptic and stimulant and is used in treatment of snake bite (Jain, 1991; Krithikar and Basu, 1993) and antispasmodic pills are made from root (Jain, 1991; Manilal, 2003). 
In addition to its medicinal value various parts of $A$. monophylla is used for several other purposes. Juice of berries is used for dyeing purposes. Wood is a good source of timber. It is also useful as a rootstock for breeding new cultivars of Citrus Linn (Guhabhakshi et al., 1999). Decoction of leaves of A. racemosa is used in the treatment of bronchitis, asthma and cough. The leaves are chewed to get relief from bronchitis. Leaf powder is used as blood purifier and decoction of the leaf is given every night as blood purifier. One tea spoon powder is given in cough and sour throat for 6 hours. Also a tea spoon of root powder is given every night as blood purifier (Pullaiah, 2006). The Kurichia tribes are using the leaf juice of $A$. racemosa Wight var. racemosa internally to treat acidity (Deviprasad et al., 2013). The ripe and unripe fruits are eaten by Paliyars (Arinathan et al., 2007). Also the fruits are pickled and eaten by several tribal groups such as Kurumba gounder, Sadaya gounder, Ariyan, Muthuvan and Kattunaikkan (Das et al., 2013). Kadars, Malasars and Muthuvan tribals of Anamalai hills use the whole plant of A. wightii to stupefy the fishes (Hosagoudar and Henry, 1996). Earlier works in A. wightii revealed the presence of Coumarins (Umbeliferone and geranyl umbeliferone) (Banerji et al., 1982) and few triterpenes (lupeol, lupenone, epi-friedelinol) (Desai et al., 1977). The fruits of the members of the genus Atalantia are picked and widely consumed by the tribal people. Therefore the present study aims to test the anti-oxidant potential of the methanol extracts of fruits and also to identify the bioactive compounds present in the extracts through GC/MS analysis.

\section{MATERIALS AND METHODS}

\section{Collection of plant material}

The fruits and leaves were collected from different places in south India. A. monophylla samples were collected from Nagamalai hills of Madurai district, Tamil Nadu. A. racemosa and A. wightii were collected from Meghamalai hills, Theni, Tamil Nadu and the shola forests near Vaguvarai estate, Munnar, Kerala respectively (Fig. 1). The herbarium of the collected specimens were prepared and identified at Botanical Survey of India, Coimbatore. The herbarium specimen was deposited at the herbarium of department of Plant science, Madurai Kamaraj University. The samples were then shade dried and the moisture content of each sample was calculated.

\section{DPPH radical scavenging assay}

The DPPH reacts with methanol or ethanol to yield a purple color DPPH radical (DPPH). The presence of antioxidants which include polyphenolics and flavonoids in the sample will scavenge the formed DPPH radical and there by a decreased color will be absorbed which is spectrophotometrically measured at $517 \mathrm{~nm}$. To $0.5 \mathrm{ml}$ of DPPH solution, add $2 \mathrm{ml}$ of the extract (100$1000 \mu \mathrm{g} / \mathrm{ml}$ ) and the reaction mixture is vortexed for $10 \mathrm{~s}$ and allow standing at room temperature for 30 minutes. The absorbance is recorded at $517 \mathrm{~nm}$ by using UV-Vis spectrophotometer. Compare with the $75 \%$ ethanol which acts as control solution. Ascorbic acid is used as reference antioxidant compound.
The percentage of DPPH radical scavenging activity is expressed as

[1 - (Test sample absorbance/Blank sample absorbance] $\times 100(\%)$.

\section{Phosphomolybdenum method}

Antioxidant present in the sample reduce the $\mathrm{Mo}(\mathrm{VI})$ to $\mathrm{Mo}(\mathrm{V})$ which then react with the phosphate group sodium phosphate to form a green colored $\mathrm{Mo}(\mathrm{V})$ - Phosphate complex (Phosphomolybdenum complex) in an acetic medium. This complex is then spectrophotometrically measured at $695 \mathrm{~nm}$. The tubes containing $0.2 \mathrm{ml}$ of extract $(100-1000 \mu \mathrm{g} / \mathrm{ml})$ is mixed with $1.8 \mathrm{ml}$ of distilled water, $2 \mathrm{ml}$ of Phosphomolybdenum reagent solution. Incubate it at $95^{\circ} \mathrm{C}$ for 90 minutes. The mixture is closed to room temperature and the absorbance is measured at $695 \mathrm{~nm}$ against reagent blank. The antioxidant capacity is expressed as Ascorbic Acid Equivalent (AAE).

\section{GC/MS analysis of plant extracts}

A Shimadzu QP-2010 plus with thermal desorption system TD 20 was used to obtain the chromatograms. The name and specification of the column used is Rtx ${ }^{\circledR}-5 \mathrm{MS}$ (30m X 0.25 $\mathrm{mm}$ i.d. X 0.25 um film thickness). For GC-MS detection, an electron ionization system was operated in electron impact mode with ionization energy of $70 \mathrm{eV}$. Helium gas (99.999\%) was used as a carrier gas at a constant flow rate of $1 \mathrm{ml} / \mathrm{min}$, and an injection volume of $2 \mu$ was employed (a split ratio of 10:1). The injector temperature was maintained at $260{ }^{\circ} \mathrm{C}$, the ion-source temperature was $230{ }^{\circ} \mathrm{C}$, the oven temperature was programmed from $100{ }^{\circ} \mathrm{C}$ (isothermal for $3 \mathrm{~min}$ ), with an increase of $10{ }^{\circ} \mathrm{C} / \mathrm{min}$ to $250{ }^{\circ} \mathrm{C}$, then $20{ }^{\circ} \mathrm{C} / \mathrm{min}$ to $380{ }^{\circ} \mathrm{C}$, ending with a $19 \mathrm{~min}$ isothermal at $380{ }^{\circ} \mathrm{C}$. Mass spectra were taken at $70 \mathrm{eV}$; a scan interval of $0.5 \mathrm{~s}$ and fragments from 40 to $650 \mathrm{Da}$. The relative percentage amount of each component was calculated by comparing its average peak area to the total areas. The components were identified based on the library search carried out using NIST and WILEY library.

\section{RESULTS}

\section{DPPH radical scavenging activity}

DPPH radical scavenging activity was tested to analyze the antioxidant potential of the methanol extracts of fruits of Atalantia species. Vitamin C (Ascorbic acid) was used as the standard and was compared with the sample for calculating the anti oxidant activity. Among the three fruits tested for the antioxidant activity using the DPPH method, the crude methanolic extracts of $A$. monophylla shows higher potential. All the three extracts show similar results. The percentage inhibition of methanolic extract of fruits was found to be $82.55 \%, 72.4 \%$ and 80.04 at $1000 \mu \mathrm{g}$ concentration in A. monophylla, A. racemosa and A. wightii respectively (Fig. 2). Ascorbate used as standard showed $94.3 \%$ inhibition at $1000 \mu \mathrm{g}$ concentration. The $\mathrm{IC}_{50}$ value calculated was found to be $336.84 \mu \mathrm{g} / \mathrm{ml}$ for A. monophylla, $348.75 \mu \mathrm{g} / \mathrm{ml}$ for $A$. racemosa and $375.64 \mu \mathrm{g} / \mathrm{ml}$ for $A$. wightii. 
Ascorbic acid used as standard had an $\mathrm{IC}_{50}$ value of $103.03 \mu \mathrm{g} / \mathrm{ml}$ (Table 1).

Table 1: $\mathrm{IC}_{50}$ values of DPPH radical scavenging activity of Methanol extracts of three species of Atalantia compared with the standard (Vitamin C).

\begin{tabular}{cc}
\hline Plant Name & $\mathbf{I C}_{\mathbf{5 0}}(\boldsymbol{\mu g} / \mathbf{m l})$ \\
\hline A. monophylla & $336.84 \pm 44.71$ \\
A. racemosa & $348.75 \pm 11.19$ \\
A. wightii & $375.64 \pm 15.17$ \\
Vitamin C & $103.03 \pm 32.067$ \\
\hline
\end{tabular}

\section{Phosphomolybdenum method}

Total antioxidant capacity was expressed as ascorbic acid equivalent and was calculated using the Phosphomolybdenum method. The methanol extract of A. monophylla, A. racemosa and A. wightii exhibited significant antioxidant activity of $686 \mathrm{mg} / \mathrm{g}$, $592 \mathrm{mg} / \mathrm{g}$ and $655 \mathrm{mg} / \mathrm{g}$ respectively (Table 2). The fruit of $A$. racemosa showed the maximum antioxidant activity among the three species.

Table 2: Total antioxidant capacity of three species of Atalantia by Phosphomolybdenum method.

\begin{tabular}{cc}
\hline Plant Name & Ascorbic acid equivalent \\
\hline A. monophylla & $686 \mathrm{mg} / \mathrm{g}$ \\
A. racemosa & $592 \mathrm{mg} / \mathrm{g}$ \\
A. wightii & $655 \mathrm{mg} / \mathrm{g}$ \\
\hline
\end{tabular}

\section{GC-MS analysis of methanol extract of the three Atalantia species}

The bioactive compounds in the Methanol extract of $A$. monophylla were evaluated using GC/MS. The analysis was done using Shimadzu QP-2010 plus with thermal desorption system TD 20, while the mass spectra of the compounds found in the extract was matched with the National Institute of Standards and Technology (NIST) library. Twenty seven compounds were identified from the mass spectra obtained. 1,3,4,5-Tetrahydroxycyclohexanecarboxylic acid was the major compound identified. In A. racemosa also 27 compounds were identified and nHexadecanoic acid was the major compound. In A. wightii 18 compounds were identified. $\beta$-Sitosterol was the major component in the methanolic extract of $A$. wightii. $\beta$-Sitosterol and Stigmasterol was present in all the three species (Table 3-5).

$\beta$-sitosterol is a very good for reducing the cholesterol levels in the blood and is sometimes used in treating hypercholesterolemia. The way of action is that $\beta$-Sitosterol inhibits cholesterol absorption in the intestinal absorption by competing thereby reducing the serum cholesterol levels (Matsuoka et al., 2008). It also shows anti-inflammatory and antipyretic activities (Gupta et al., 1980). Stigmasterol is used as a precursor for the manufacture of semisynthetic progesterone (Sundararaman and Djerassi, 1997). It is reported to be useful in prevention of ovarian, prostate, breast, and colon cancers (Ghosh et al., 2011). Stigmasterol also possesses anti-osteoarthritis and cholesterol lowering activity (Chen et al., 2012).
Table 3: Compounds identified from the methanol extract of A. monophylla fruit using GC-MS

\begin{tabular}{|c|c|c|c|c|}
\hline $\begin{array}{l}\dot{z} \\
\dot{\tilde{\omega}}\end{array}$ & 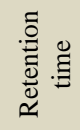 & 总 & 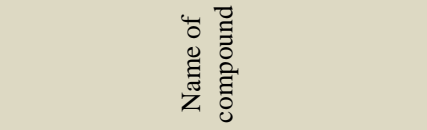 & 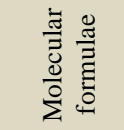 \\
\hline 1 & 5.58 & 0.39 & 2,3-Dihydro-benzofuran & $\mathrm{C}_{8} \mathrm{H}_{8} \mathrm{O}$ \\
\hline 2 & 5.86 & 11.40 & 5-Hydrxoymethylfurfural & $\mathrm{C}_{6} \mathrm{H}_{6} \mathrm{O}_{3}$ \\
\hline 3 & 6.85 & 8.91 & p-Vinylguaiacol & $\mathrm{C}_{9} \mathrm{H}_{10} \mathrm{O}_{2}$ \\
\hline 4 & 8.20 & 3.24 & 4-Hydroxy-3-methoxy-benzaldehyde & $\mathrm{C}_{8} \mathrm{H}_{8} \mathrm{O}_{3}$ \\
\hline 5 & 9.85 & 0.24 & Guaiacylacetone & $\mathrm{C}_{10} \mathrm{H}_{12} \mathrm{O}_{3}$ \\
\hline 6 & 9.97 & 0.62 & 5(Hydroxymethyl)spiro[2.4]heptan-5-ol & $\mathrm{C}_{8} \mathrm{H}_{14} \mathrm{O}_{2}$ \\
\hline 7 & 10.22 & 1.04 & $\begin{array}{l}\text { 3,5-Dimethoxy-4- } \\
\text { hydroxycinnamaldehyde }\end{array}$ & $\mathrm{C}_{11} \mathrm{H}_{12} \mathrm{O}_{4}$ \\
\hline 8 & 10.57 & 0.40 & Sinapinaldehyde & $\mathrm{C}_{11} \mathrm{H}_{12} \mathrm{O}_{4}$ \\
\hline 9 & 10.68 & 0.89 & m-Anisic acid & $\mathrm{C}_{8} \mathrm{H}_{8} \mathrm{O}_{4}$ \\
\hline 10 & 11.25 & 0.59 & 1-Piperidino-1-cyclopentene & $\mathrm{C}_{10} \mathrm{H}_{17} \mathrm{~N}$ \\
\hline 11 & 12.14 & 40.83 & $\begin{array}{l}\text { 1,3,4,5-Tetrahydroxy- } \\
\text { cyclohexanecarboxylic acid }\end{array}$ & $\mathrm{C}_{7} \mathrm{H}_{12} \mathrm{O}_{6}$ \\
\hline 12 & 12.40 & 4.09 & (E)-Conipheryl alcohol & $\mathrm{C}_{10} \mathrm{H}_{12} \mathrm{O}_{3}$ \\
\hline 13 & 14.00 & 0.30 & Hexadecanoic acid, methyl ester & $\mathrm{C}_{17} \mathrm{H}_{34} \mathrm{O}_{2}$ \\
\hline 14 & 14.45 & 2.34 & n-Hexadecanoic acid & $\mathrm{C}_{16} \mathrm{H}_{32} \mathrm{O}_{2}$ \\
\hline 15 & 15.05 & 0.31 & Juvabione & $\mathrm{C}_{16} \mathrm{H}_{26} \mathrm{O}_{3}$ \\
\hline 16 & 15.62 & 0.14 & Bornyl isovalerate & $\mathrm{C}_{15} \mathrm{H}_{26} \mathrm{O}_{2}$ \\
\hline 17 & 16.11 & 1.15 & 9-Hexadecenoic acid & $\mathrm{C}_{16} \mathrm{H}_{30} \mathrm{O}_{2}$ \\
\hline 18 & 16.30 & 0.36 & Octadecanoic acid & $\mathrm{C}_{18} \mathrm{H}_{36} \mathrm{O}_{2}$ \\
\hline 19 & 16.81 & 9.77 & Scyllo-Inositol & $\mathrm{C}_{6} \mathrm{H}_{12} \mathrm{O}_{6}$ \\
\hline 20 & 18.04 & 7.64 & Butyl benzyl phthalate & $\mathrm{C}_{19} \mathrm{H}_{20} \mathrm{O}_{4}$ \\
\hline 21 & 19.81 & 0.28 & o-Phthalic acid & $\mathrm{C}_{8} \mathrm{H}_{6} \mathrm{O}_{4}$ \\
\hline 22 & 25.27 & 0.24 & 3-Bromocholest-5-ene & $\mathrm{C}_{27} \mathrm{H}_{45} \mathrm{Br}$ \\
\hline 23 & 25.55 & 1.60 & Stigmasterol & $\mathrm{C}_{29} \mathrm{H}_{48} \mathrm{O}$ \\
\hline 24 & 25.97 & 2.55 & $\beta$-Sitosterol & $\mathrm{C}_{29} \mathrm{H}_{50} \mathrm{O}$ \\
\hline 25 & 27.03 & 0.20 & Stigmasterol & $\mathrm{C}_{29} \mathrm{H}_{48} \mathrm{O}$ \\
\hline 26 & 27.14 & 0.17 & Brassicasterol & $\mathrm{C}_{28} \mathrm{H}_{46} \mathrm{O}$ \\
\hline 27 & 27.38 & 0.28 & $\gamma$-Sitosterol & $\mathrm{C}_{29} \mathrm{H}_{50} \mathrm{O}$ \\
\hline
\end{tabular}

Table 4: Compounds identified from the methanol extract of $A$. racemosa fruit using GC/MS.

\begin{tabular}{|c|c|c|c|c|}
\hline Sl. No & R. Time & Area\% & Name & $\begin{array}{l}\text { Molecular } \\
\text { formula }\end{array}$ \\
\hline 1 & 12.34 & 2.21 & Tetradecanoic acid & $\mathrm{C}_{14} \mathrm{H}_{28} \mathrm{O}_{2}$ \\
\hline 2 & 13.39 & 0.67 & Pentadecanoic acid & $\mathrm{C}_{15} \mathrm{H}_{30} \mathrm{O}_{2}$ \\
\hline 3 & 14.00 & 0.24 & $\begin{array}{l}\text { Hexadecanoic acid, methyl } \\
\text { ester }\end{array}$ & $\mathrm{C}_{17} \mathrm{H}_{34} \mathrm{O}_{2}$ \\
\hline 4 & 14.25 & 0.23 & 9-Hexadecenoic acid & $\mathrm{C}_{16} \mathrm{H}_{32} \mathrm{O}_{2}$ \\
\hline 5 & 14.52 & 36.94 & n-Hexadecanoic acid & $\mathrm{C}_{18} \mathrm{H}_{32} \mathrm{O}_{2}$ \\
\hline 6 & 15.40 & 0.55 & Eicosanoic acid & $\mathrm{C}_{20} \mathrm{H}_{40} \mathrm{O}_{2}$ \\
\hline 7 & 15.91 & 0.21 & $\begin{array}{l}\text { Octadecanoic acid, methyl } \\
\text { ester }\end{array}$ & $\mathrm{C}_{19} \mathrm{H}_{38} \mathrm{O}_{2}$ \\
\hline 8 & 16.19 & 16.08 & $\begin{array}{l}\text { Heptadecene-(8)-carbonic } \\
\text { acid-(1) }\end{array}$ & $\mathrm{C}_{18} \mathrm{H}_{34} \mathrm{O}_{2}$ \\
\hline 9 & 16.37 & 3.96 & Octadecanoic acid & $\mathrm{C}_{18} \mathrm{H}_{36} \mathrm{O}_{2}$ \\
\hline 10 & 16.54 & 0.65 & 1,4-Didecylbenzene & $\mathrm{C} 26 \mathrm{H} 46$ \\
\hline 11 & 16.90 & 0.47 & Linoleic acid & $\mathrm{C}_{18} \mathrm{H}_{32} \mathrm{O}_{2}$ \\
\hline 12 & 17.36 & 0.37 & $\begin{array}{l}\text { Heptadecyl } \\
\text { heptafluorobutyrate }\end{array}$ & $\mathrm{C}_{21} \mathrm{H}_{35} \mathrm{~F}_{7} \mathrm{O}_{2}$ \\
\hline 13 & 17.98 & 0.21 & n-Hexadecylaniline & $\mathrm{C}_{22} \mathrm{H}_{39} \mathrm{~N}$ \\
\hline 14 & 18.24 & 0.25 & 1-Chlorotetradecane & $\mathrm{C}_{14} \mathrm{H}_{29} \mathrm{Cl}$ \\
\hline 15 & 19.15 & 0.45 & 1-Decanol, 2-hexyl & $\mathrm{C}_{16} \mathrm{H}_{34} \mathrm{O}$ \\
\hline 16 & 19.81 & 0.93 & n-Octyl phthalate & $\mathrm{C}_{24} \mathrm{H}_{38} \mathrm{O}_{4}$ \\
\hline 17 & 24.39 & 2.77 & 1-Octacosanol & $\mathrm{C}_{28} \mathrm{H}_{58} \mathrm{O}$ \\
\hline 18 & 24.71 & 0.12 & Cholesta-3,5-diene & $\mathrm{C}_{27} \mathrm{H}_{44}$ \\
\hline 19 & 25.37 & 0.41 & $\begin{array}{l}(3 \beta, 22 \mathrm{E})-3 \text { - } \\
\text { Methoxystigmasta-5,22-diene }\end{array}$ & $\mathrm{C}_{30} \mathrm{H}_{50} \mathrm{O}$ \\
\hline 20 & 25.67 & 0.41 & $\begin{array}{l}\text { (22E)-Stigmasta-4,6,22- } \\
\text { trien-3-yl acetate }\end{array}$ & $\mathrm{C}_{31} \mathrm{H}_{48} \mathrm{O}_{2}$ \\
\hline 21 & 25.83 & 10.52 & Stigmasterol & $\mathrm{C}_{29} \mathrm{H}_{48} \mathrm{O}$ \\
\hline 22 & 26.05 & 1.34 & Cholesta-4,6-dien-3-ol & $\mathrm{C}_{27} \mathrm{H}_{44} \mathrm{O}$ \\
\hline 23 & 26.20 & 17.38 & $\beta$ - Sitosterol & $\mathrm{C}_{29} \mathrm{H}_{50} \mathrm{O}$ \\
\hline 24 & 26.44 & 0.19 & $\begin{array}{l}\text { 22,23-Dibromostigmasterol } \\
\text { acetate }\end{array}$ & $\mathrm{C}_{31} \mathrm{H}_{50} \mathrm{Br}_{2} \mathrm{O}_{2}$ \\
\hline 25 & 26.96 & 0.31 & Campesterol & $\mathrm{C}_{28} \mathrm{H}_{48} \mathrm{O}$ \\
\hline 26 & 27.14 & 1.69 & Stigmasta-5,22-dien-3-ol & $\mathrm{C}_{31} \mathrm{H}_{50} \mathrm{O}_{2}$ \\
\hline 27 & 28.39 & 0.37 & Stigmast-4-en-3-one & $\mathrm{C}_{29} \mathrm{H}_{48} \mathrm{O}$ \\
\hline
\end{tabular}



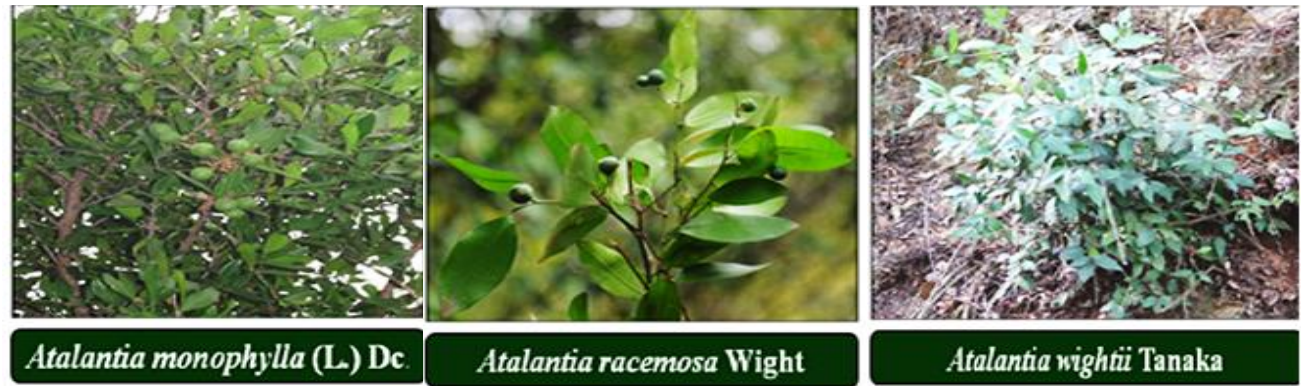

Atalantia racemosa Wight

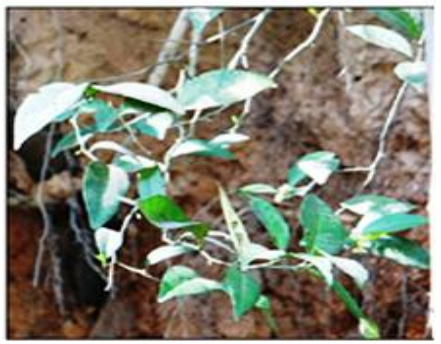

Fig. 1: Habit of three species of Atalantia in south India.

Table 5: Compounds identified from the methanol extract of A. wightii fruit using GC/MS.

\begin{tabular}{|c|c|c|c|c|}
\hline $\begin{array}{l}\stackrel{\circ}{z} \\
\dot{\pi}\end{array}$ & 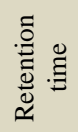 & 总 & 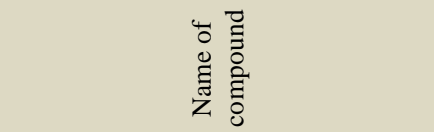 & 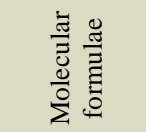 \\
\hline 1 & 14.05 & 10.15 & Hexadecanoic acid, methyl ester & $\mathrm{C}_{17} \mathrm{H}_{34} \mathrm{O}_{2}$ \\
\hline 2 & 14.48 & 12.20 & n-Hexadecanoic acid & $\mathrm{C}_{16} \mathrm{H}_{32} \mathrm{O}_{2}$ \\
\hline 3 & 15.72 & 2.82 & 9-Octadecenoic acid (Z)-, methyl ester & $\mathrm{C}_{19} \mathrm{H}_{36} \mathrm{O}_{2}$ \\
\hline 4 & 15.77 & 1.66 & Methyl 10-undecenoate & $\mathrm{C}_{12} \mathrm{H}_{22} \mathrm{O}_{2}$ \\
\hline 5 & 15.94 & 2.56 & Heptadecanoic acid, methyl ester & $\mathrm{C}_{18} \mathrm{H}_{36} \mathrm{O}_{2}$ \\
\hline 6 & 16.21 & 3.54 & 5-Isopropyl-1,3-cyclohexanedione & $\mathrm{C}_{9} \mathrm{H}_{14} \mathrm{O}_{2}$ \\
\hline 7 & 16.34 & 0.87 & $\begin{array}{l}\text { Propanoic acid, 2-methyl-, 3-hydroxy- } \\
\text { 2,4,4-trimethylpentyl ester }\end{array}$ & $\mathrm{C}_{12} \mathrm{H}_{24} \mathrm{O}_{3}$ \\
\hline 8 & 17.42 & 3.43 & $\begin{array}{l}\text { 7-Methoxy-8-(2-oxo-3- } \\
\text { methylbutyl)coumarin }\end{array}$ & $\mathrm{C}_{15} \mathrm{H}_{16} \mathrm{O}_{4}$ \\
\hline 9 & 17.69 & 0.68 & Undecanoic acid, methyl ester & $\mathrm{C}_{12} \mathrm{H}_{24} \mathrm{O}_{2}$ \\
\hline 10 & 18.11 & 0.87 & $\begin{array}{l}\text { (1R,4R,5R)-2-Benzyl-7,7-dimethyl-6,8- } \\
\text { dioxa-2-azabicyclo[3.4.0]nonan-4-one }\end{array}$ & $\mathrm{C}_{15} \mathrm{H}_{19} \mathrm{NO}_{3}$ \\
\hline 11 & 19.84 & 0.70 & Phthalic acid, ditridecyl ester & $\mathrm{C}_{34} \mathrm{H}_{58} \mathrm{O}_{4}$ \\
\hline 12 & 24.40 & 3.44 & 1,1-Dichloro-2-dodecanol & $\mathrm{C}_{12} \mathrm{H}_{24} \mathrm{C}_{12} \mathrm{O}$ \\
\hline 13 & 25.60 & 4.08 & 22,23-Dibromostigmasterol acetate & $\mathrm{C}_{31} \mathrm{H}_{50} \mathrm{Br}_{2} \mathrm{O}_{2}$ \\
\hline 14 & 25.82 & 16.14 & Stigmasterol & $\mathrm{C}_{29} \mathrm{H}_{48} \mathrm{O}$ \\
\hline 15 & 25.96 & 2.89 & $\begin{array}{l}\text { Cholest-5-en-3-ol (3.beta.)-, } \\
\text { tetradecanoate }\end{array}$ & $\mathrm{C}_{41} \mathrm{H}_{72} \mathrm{O}_{2}$ \\
\hline 17 & 26.19 & 30.97 & $\beta$-Sitosterol & $\mathrm{C}_{29} \mathrm{H}_{50} \mathrm{O}$ \\
\hline 18 & 27.16 & 2.70 & Stigmasterol & $\mathrm{C}_{29} \mathrm{H}_{48} \mathrm{O}$ \\
\hline
\end{tabular}

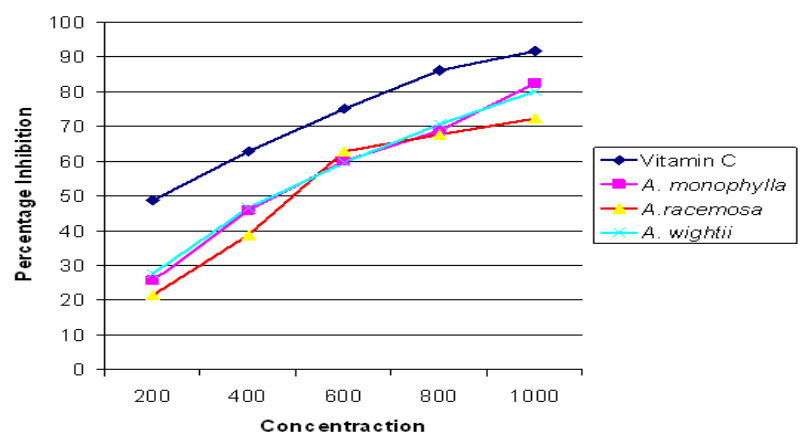

Fig. 2: DPPH radical scavenging activity of three species of Atalantia compared with the standard (Vitamin C).

\section{ACKNOWLEDGEMENT}

Authors thank Mr. Ajay Kumar of Advanced instrumentation research facility, JNU, New Delhi for extending help in GC/MS analysis. PSS thanks UGCCAS, DST-IPLS and DST-Purse programme for partial financial support through research grants.

\section{REFERENCES}

Arinathan V, Mohan VR, John De Britto A. Ethnomedicinal survey among Palliyar tribals of Srivilliputhur Grizzled Giant Squirrel Wildlife Sanctuary, Tamil Nadu. Journal of Economic and Taxonomic Botany, 2003; 27:707-710.

Banerji J, Ghoshal N, Sarkar S, Kumar M. Studies of Rutaceae. 2. Chemical investigation of the constituents of Atlantia wightii, Limonia creniaulata, Feronia limonia, Citrus limon and synthesis of luvangetin, xanthyletin and marmin. Indian J Chem, 1982; 21B:496-498.

Chen W, Chong Y, Peng-Fei H, Jia-Peng B, Jing-Li T, Li-Dong W. Stigmasterol blocks cartilage degradation in rabbit model of osteoarthritis. Acta biochim Pol, 2012; 59(4):537-541.

Das AK, Stalin N, Muthuperumal C, Swamy PS. Wild plants used by Muthuvan and Kattunaikkan tribal communities of Palakkayam settlement in Nilambur of Malappuram district, Kerala. Medicinal PlantsInternational journals of Phytomedicines and Related Industries, 2013; $5(2): 82-89$

Desai HK, Gaward DH, Joshi BS, Parthasarathy PC, Ravindranath KR, Saindane MT, Shidhaya AR, Viswanathan N. Chemical Investigation of Indian Plants, Part X . Indian J Chem, 1977; 15B:291.

Ghosh A, Chowdhury N, Chandra F. Plant extracts as potential mosquito larvicides. Indian Journal of Medicinal Plants Research, 2012 135:581-589.

Guhabakshi DN, Sensarma P, Pal DC. 1999. A lexicon of medicinal plants in India. Naya Prokosh publications. p. 212.

Gupta MB, Nath R, Srivastava N, Shanker K, Kishor K, Bhargava KP. Anti-inflammatory and antipyretic activities of betasitosterol. Planta Medica, 1980; 39:157-63.

Hosagoudar VB, Henry AN. Ethnobotany of Kadars, Malasars and Muthuvans of the Anamalais in Coimbatore district, Tamil Nadu, India. Journal of Economic and Taxonomic Botany, 1996; 12:260-267.

Jain SK. 1991. Disctionary of Indian folk - medicine and Ethnobotany. Danvers Educational Enrichment Partnership, Publisher, New Delhi. 
John De Britto A, Mahesh R. Exploration of Kani tribal Botanical knowledge in Agasthiayamalai Biosphere reserve - south India. Ethnobotanical leaflets, 2007; 11:258-265.

Khare CP. 2007. Medicinal plants: An illustrated Dictionary, Springer. pp.22.

Kirtikar KR, Basu BD. 1999. Indian Medicinal Plants. Bishen Sing, Mahendra Pal Sing publication. pp.1655-1656.

Manilal KS. 2003. Van Rheed's Hortus Malabaricus, University of Kerala, Vol 14: pp.39.

Matsuoka K, Nakazawa T, Nakamura A, Honda C, Endo K, Tsukada M. Study of Thermodynamic Parameters for Solubilization of Plant Sterol and Stanol in Bile Salt Micelles. Chem Phys Lipids, 2008; 154(2):87-93.

Mohapatra AK. Food and feeding behaviour of Asiatic Elephant (Elephas maximus linn.) in Kuldiha wild life sanctuary, Odisha, India. J Environ Biol, 2013; 34:87-92.

Panda H. 2004. Handbook on Medicinal Herbs with Uses. Asia Pacific Business Press Inc. pp.166-167.

Pullaiah T. 2006. Encyclopaedia of World Medicinal Plants. Regency Publisher, New Delhi. p.2442.

Punekar SA. Some Food Plants Of Hanuman Langur Senopithecus entellus (Dufrensne) in the Western Ghats of Maharashtra, India. Zoos Print Journal, 2002; 17(6):797-801.

Rajasekar R. Depositing masticated plant materials inside tent roosts in Cynopterus sphinx (Chiroptera: Pteropodidae) in Southern India. Acta Chiropterologica, 2006; 8(1):269-274.
Shyma TB, Devi Prasad AG. Traditional use of medicinal plants and its status among the tribes in Mananthavady of Wayanad district, Kerala. World Research Journal of Medicinal and Aromatic Plants, 2012; 1(2):22-26.

Storz JF, Kunz TH. Cynopterus sphinx. The American Society of Mammalogists, 1999; 613(4):1-8.

Sundararaman P, Djerassi CA. Convenient synthesis of progesterone from Stigmasterol. J Org Chem, 42(22):3633-3634.

Swingle WT, Reece PC. 1967. The botany of Citrus and its wild relatives. In: Reuther, W., Webber, H.J. and Batchelor, L.D [eds.], The citrus industry, vol. 1, History, world distribution, botany, and varieties. University of California, Berkeley, California, USA.

Vanitharani J. Role of Cynopterus brachyotis (lesser dog Faced fruit bat), Cynopterus sphinx (short Nosed fruit bat) in forest restoration of Kalakad mundanthurai tiger reserve. Recent Advances in Biodiversity of India, 2011; 51:447-467.

\section{How to cite this article:}

Das AK, Swamy S. Antioxidant activity and determination of bioactive compounds by GC-MS in fruit methanol extracts-A comparative analysis of three Atalantia species from south India. J App Pharm Sci, 2016; 6 (02): 130-134. 